inOedia $\quad \begin{aligned} & \text { InMedia } \\ & \text { The French Journal of Media Studies }\end{aligned}$

6 | 2017

Fields of Dreams and Messages

\title{
21st SERCIA Conference: Cinema and Seriality in the English-speaking World
}

\section{Ann-Lys Bourgognon}

\section{(2) OpenEdition}

12 Journals

\section{Electronic version}

URL: http://journals.openedition.org/inmedia/878

DOI: $10.4000 /$ inmedia. 878

ISSN: 2259-4728

\section{Publisher}

Center for Research on the English-Speaking World (CREW)

\section{Electronic reference}

Ann-Lys Bourgognon, «21st SERCIA Conference: Cinema and Seriality in the English-speaking World », InMedia [Online], 6 | 2017, Online since 18 December 2017, connection on 24 September 2020. URL http://journals.openedition.org/inmedia/878 ; DOI : https://doi.org/10.4000/inmedia.878

This text was automatically generated on 24 September 2020

(C) InMedia 


\title{
21st SERCIA Conference: Cinema and Seriality in the English- speaking World
}

\author{
Ann-Lys Bourgognon
}

\section{EDITOR'S NOTE}

Conference Organized by Ariane Hudelet and Anne Crémieux

\section{AUTHOR'S NOTE}

More information on the SERCIA and its activities can be found on their website and on Facebook (@Sercia).

1 The $22^{\text {nd }}$ edition of the annual conference of SERCIA was organized by Ariane Hudelet (University of Paris Diderot) and Anne Crémieux (University of Paris X Nanterre) and welcomed a great variety of researchers who came together to reflect upon the notion of seriality within both cinema and television series. ${ }^{1}$ Among the international guests (who came from, for instance, the USA, England, Switzerland and Italy), the conference was highlighted by two keynote speakers: Scott Higgins from Wesleyan University in Middletown, CT, and Samuel Chambers, from Johns Hopkins University in Baltimore, MD.

2 The program aimed to emphasize the different levels at which seriality can be analyzed: some panels focused on the production of films and their possible sequels, reboots and remakes, therefore drawing attention to the influence of seriality on the film market, viewership or transmedial practices. For instance, Célia Sauvage (University of Paris II Sorbonne Nouvelle) compared Hollywood's rather commercial sequels and more intentional and critically appreciated auteurist ones. Other workshops explored specific categories, such as the horror genre (Martial Martin from 
the University of Reims studied Scream in both its cinematographic and serial versions), TV series and serials, documentaries (a whole workshop was devoted to the genre and chaired by Nicole Cloarec from the University of Rennes I) or superhero films. Finally, some talks investigated the more theoretical aspects and issues raised by the notion of seriality in film and series, often exploring seriality within a narratological frame, or adapting concepts taken from film theory. While Elise Harris (University of Chapel Hill) focused on the aestheticization of time allowed by the form of the TV series, Claire Cornillon close-read Josh Whedon's Dollhouse to unveil its narrative complexity. As a result, conventions and genre codes, sequels and their variations, were explored, as well as viewer practices and such concepts as repetition, figurative seriality, discontinuity and the treatment of time in sequels which give an impression of circularity, or in long-running TV series faced with the inevitable aging of their actors.

Some of these questions were elucidated by the two in-depth keynote talks which were given during the conference. Scott Higgins first took the audience on a journey through the serial Captain America. He redefined what some critics dismissed as narrative inconsistencies in order to read the 1940's action-packed 15-minute stories as a goldmine for detail-savvy connoisseurs who look beyond systematic and unbelievable cliffhangers to focus on technological treasures, flamboyant fight scenes and the endless safe adventure provided by an ever-open show, something only such serial clockwork formatting could provide.

4 Samuel Chambers provided subtle insight on the CBS TV series The Good Wife (2009-2016), intricately weaving queer theory current debates about antinormativity and Foucault's underestimated notion of subject-position with the concept of seriality defined as a normative force in the context of a primetime network show highly reactive to real events and viewers' reactions. Focusing mostly on main character Alicia Florrick, a stay-at-home mother who went back to work at a law firm after her husband's scandalous resignation, Chambers proceeded to show how she diverged from the roles society tried to categorize her in (and referred to in the series' title), therefore challenging and critiquing the normative forces at work behind subject positions.

Over the three days of the conference, seriality appeared to be at the crossroads of many on-going reflections on both cinema and TV series as quickly evolving media. The changes they are currently undergoing are partially due to the Internet and the new forms of viewership it has generated, like streaming and binge watching, which in turn heavily modified the industries and markets. The notions entailed in seriality seem, therefore, to be caught between aspects highly valued by critics -- involving the treatment of time, character development, and complex narrative -- and more commonly disregarded effects of repetition, use of sequels for commercial reasons, sometimes at the expense of narrative coherence, quality or originality. However, many papers have outlined intersecting observations between these two poles, suggesting that even in the most popular forms of serial or cinematic entertainment, seriality constantly questions the origin(s) and closure(s) of a narrative while providing many layers of interpretation depending on the viewers' culture and knowledge. The idea that repetition generates new meanings thanks to the very action of showing an element over and over again also allowed many speakers to reflect on irony and the often-found distance and "meta" dimension that serial narratives can take - especially those belonging to the horror genre. The image of the ghost provides a vivid metaphor for many of the topics which were evoked: while only a few of the talks dealt with 
actual ghosts, the fact that some characters or elements of a show or film constantly reappeared definitely evoked spectrality, similarly to the more remote, haunting presence of literature or other artistic media which invites one to further reflect on seriality in intertexts.

6 Representative of serial complexity and interplay in TV and cinema was the parallel drawn by Francisco Ferreira (University of Poitiers) between the horror film Nightmare on Elm Street (Wes Craven, 1984) featuring Freddy Krueger, a dead man coming back in the dreams of young teenagers to seek revenge, and Derrida's to-the-point summary of Shakespeare's Hamlet: "Enter the ghost, exit the ghost, re-enter the ghost".

\section{ENDNOTES}

1. Due to the very large number of panels, not all of them could be covered in this report.

\section{AUTHOR}

\section{ANN-LYS BOURGOGNON}

Ann-Lys Bourgognon is doing a PhD in English at the Université du Havre

Université Paris Diderot, Paris, France, September 8-10, 2016 